\title{
Rethinking Outreach: Collaboration Is Key for Herbicide-Resistance Management
}

\author{
Amy Asmus and Jill Schroeder*
}

\begin{abstract}
Effective outreach is critical to achieving success in managing herbicide-resistant weeds. Interdisciplinary collaboration is needed to adapt information delivery and to engage communities to address the herbicide-resistance problem. Weed scientists must partner with the production community to adapt herbicide-resistance practices for local needs, to work collaboratively with state and regional stakeholders to create effective resistance-management practices, and to provide an overarching national message as to the causes of, and solutions to, resistance.
\end{abstract}

Key words: Community approaches, interdisciplinary collaboration, outreach.

Although we all must acknowledge that some rate of resistance evolution in weeds will occur no matter what practices of control are implemented, the weed science community is in agreement that, to effectively minimize the evolution of, or to control, herbicide-resistant weeds, farmers must diversify their management practices (Norsworthy et al. 2012; Owen 2014; Soteres et al. 2011). The overall goal, therefore, is to achieve cropping systems with diverse weed management tailored to local farm and operator conditions (Shaw 2014). Diversity in weed management requires developing long-term management approaches for individual fields that use appropriate tactics based on regular monitoring and mapping of weed populations (Owen 2014). The second Herbicide Resistance Summit (http://wssa. net/weed/resistance-summit-ii/) focused on how the problem of herbicide-resistant weeds is complicated and how we need to understand the human dimension of the problem to effectively identify solutions. In this article, we present our thoughts about why effective, comprehensive, and collaborative outreach is critical to achieving this long-term goal. For clarity, we defined terms used herein as follows: adviser is any individual that a grower looks to for advice in how to manage their crop or production operation, which may include independent crop consultants, input retail agronomist, farm managers, bankers, extension specialist, other farmers, land owners, government agencies, such as the Natural Resources Conservation Service, chemical manufacture representatives, and many others; community is a collection of stakeholders that are

\footnotetext{
DOI: $10.1614 /$ WS-D-15-00068.1

* Certified Crop Advisor, Asmus Farm Supply, Inc., 50245 40th Avenue, Rake, IA 50465; Agronomist/Weed Scientist, USDA-Office of Pest Management Policy, Washington, DC 20250. Corresponding author’s E-mail: jischroe1@gmail.com
}

actively involved with successful crop production in a defined area; and extension or state specialist is a university extension field staff member that works with growers in the field of weed science.

Extension educators in the United States traditionally had the primary role and responsibility of explaining research results and delivering information to their clientele, primarily growers, but also farm managers, consultants, and retailers (Cloyd 2005). A survey of extension weed scientists in 2007 found most were spending more time and effort on resistance-management education than they had spent in the previous $10 \mathrm{yr}$. In addition, these same educators reported that they expected to spend even more time on resistance-management topics during the subsequent 5 yr. (Scott et al. 2009). Furthermore, a survey of U.S. consultants from the midsouth in 2011 identified a need for continued research and education focused on the management of glyphosate-resistant and -tolerant weeds (Riar et al. 2013a). Ten percent of the consultants surveyed identified the desire for research focused on cultural practices, and others expressed the need to educate farmers to help them understand the differences in management required for crops with different herbicide-resistance traits. These responses by the consultants involved were prompted by questions posed to them by weed scientists and were related to specific information that the consultants needed to be more effective. However, it is important that extension educators reflect not only on changing the focus of the information extension educators deliver around herbicide resistance but also on the importance of their role as members of the production community.

Extension services across the United States operate within the same federal priorities. However, the priorities and programs offered in each state 
vary based on local needs identified by each landgrant institution. Also, extension service programming and direct interaction between state specialists and farmers in many parts of the United States have been challenged by diminishing resources, including decreases in personnel, resulting in regionalization of activities (Cloyd 2005). All these factors lead to the reality that extension programs and what they can accomplish in resistance education vary from state to state. Some specialists within the extension service have, both individually and in partnership with other academic colleagues or industry, developed a variety of educational materials for print, Internet, and social media.

The sources of information about glyphosate resistance and the proportion of growers using those sources were identified for six states (Indiana, Illinois, Iowa, Nebraska, Mississippi, North Carolina). The results suggest that, although university extension personnel provide material, many growers rely on other trusted advisers to deliver relevant information for their operations, such as farm press publications (54 to $65 \%$ of respondents) and agriculture chemical retailers (15 to $23 \%$ of respondents) (Johnson et al. 2009). Growers surveyed in these states indicated that they rely on universities and cooperative extension less than they do other sources ( 10 to $24 \%$ of respondents). In a study of the impact of information sources on California grower perceptions, private consultants were found to be a very important source of information on pest-management issues (Farnsworth and Moffitt 1984). Although this survey was conducted more than $30 \mathrm{yr}$ ago, it illustrates the point that farmers' sources have varied among states and over time. In Iowa, $78 \%$ of farmers rely on professional advisers, primarily their agricultural chemical retailer, to assist with their weed-management decisions (Arbuckle 2014). Retailers and consultants use a variety of information sources, including university research and cooperative extension, farm press publications, and industry representatives (A Asmus, personal observation). Each of these sources has access to materials put together through extension programs and although most growers do not directly use extension services, extension specialist's information will be delivered, but often filtered, through other sources to the grower. Furthermore, easy access to information through technology and social media compounds the challenge for all members of the production community to distinguish scientific information generated by universities and industry from chat room comments and opinions, product-specific propaganda, and advertising (personal communication with Iowa growers and advisers, July 2015).

Clearly, extension specialists are working to address the issue of resistance and to provide meaningful information to their growers despite the many demands on their time and resources. However, in spite of these efforts, the number of cases of resistant species is steadily increasing both in the United States and globally (Heap 2014), suggesting that traditional extension approaches that simply deliver the message are not working because they are not engaging all the stakeholders. Our intent is not to blame the current programs but to challenge more weed scientists to think about working in new ways by partnering with the production stakeholders to use their collective knowledge to successfully integrate identified bestmanagement practices into production and by also recognizing operational, economic, or social issues that may prevent growers from properly addressing weed management (Ervin and Jussaume 2014).

Farmers are very aware of the problem of herbicide resistance (e.g., Arbuckle 2014; Givens et al. 2011; Johnson et al. 2009; Riar et al. 2013a) and yet adoption of recommended best-management practices has been selective and, in most cases, limited (e.g., Frisvold et al. 2009; Johnson et al. 2009; Owen et al. 2014; Wilson et al. 2009). Despite grower knowledge of best-management practices for herbicide-resistance management, other factors play a major part in their decision process. Impediments include operational issues, such as weather impacts, equipment constraints, and time constraints; economic issues, such as cost, when the immediate cost is certain but the long term benefit is uncertain, profitability, and product-manufacturer marketing programs; and social issues, such as government-supported crop programs constraining options, complacency, reluctance to act until the problem occurs, and reluctance to act if neighbors are not adopting similar practices; and others (e.g., Doohan et al. 2010; Givens et al. 2011; Norsworthy et al. 2012; Owen et al. 2014; Riar et al. 2013b).

Farmers are the key decision makers regarding their operations, and no two farms or fields are the same. This diversity in operations and issues faced by producers becomes greater across regions of the country as environment, cropping systems, land ownership, and resources to fund farming operations change. Growers make decisions based on personal experience and discussions with advisers, other farmers, and their network of influencers; the 
constraints of their farming operation; and their personal priorities, not just educational materials (Llewellyn and Pannell 2009; Oreszczyn et al. 2010; Wilson et al. 2009). Many growers work with a network of influencers that may include stakeholders from government, real estate, financing, production, and sales (Jussaume and Ervin 2014). The land owner and lender both affect grower decisions based on the value of the property and their goals, which often are to minimize unnecessary cost and inputs to maximize yield and annual profitability. Buyers are concerned with the quality of goods produced. Participation in government programs focused on conservation, water quality, soil health, or endangered species may affect available weedmanagement options, such as tillage or weed control within buffer strips. Traditional extension service outreach efforts rarely consider how these influencers affect production decisions nor do they consider the many other sources of information that influence farmers and their crop advisers. It is important for all educators to consider that grower decisions are not based on one or two major issues but on the overall success of the production system while still maintaining profitability for their operation.

Weed scientists have often focused on providing information to manage herbicide resistance and expect the growers to readily adopt practices based on that advice (Doohan et al. 2010; Shaw 2014). We must all rethink our approach based on a better understanding of why growers have not adopted more-diverse weed-management practices. The weed science community must reevaluate how we are communicating and interacting with the production community. Do we listen to growers and their advisers regarding their ideas and solutions for managing herbicide resistance, the constraints they deal with in their operations, and what is working or not working? Are we delivering sciencebased information in a clear, understandable format that includes data on the short- and long-term economic costs and benefits of implementing resistance practices, as well as economic consequences to the producers and their operations if they delay implementation? Are we working to develop long-term strategies that include all management tools? Are we providing farmers a realistic assessment of how to apply these new management strategies, and are we considering the ramifications of these new strategies on the overall farming operation and production system? Do we understand the drivers behind the decision-making process, with all the competing priorities and demands that impact farmers? We must partner with others to consider how each agricultural community, which includes farmers, advisers, and influencers, shares knowledge and makes decisions (Ervin and Frisvold 2014; Jussaume and Ervin 2014). A collaborative approach that involves all stakeholders as partners is needed to create effective and sustainable weed-management practices. Weed scientists all learn how to diagnose and solve weedcontrol problems in our introductory weed-science classes (e.g., Ross and Lembi 2009). This approach to solving weed problems, which is based on a thorough diagnosis of the problem and constant evaluation, leading to adaptation of programs, can be broadened and adapted to address these community-based problems. The key difference is that weed scientists must partner with social scientists and economists to consider the human factors that influence field production, and work with the entire production community to fully diagnose the problem and identify solutions that will work for that community of producers and their advisers.

\section{Local Actions}

Open dialog between the farmer and adviser allows for identification of areas in which tools and recommendations need to be reevaluated to better manage resistance on a field by field basis. Stakeholders at this level need access to accurate and current information about local resistance occurrences and spread, the tools they need to carry out resistance-management plans, and how to use and prioritize those tools in light of economic and management barriers in production. This feedback, provided by growers to those who help with management decisions, is vital so that strategies can be adapted to local conditions. We observe that an increasing number of growers use the latest technology with the intention of collecting data on such things as field properties, inputs, yields, costs, and returns throughout their production process. However, they must understand how best to use the weed-control data they collect so that future management decisions are based on sound conclusions.

\section{State and Regional Actions}

Stakeholders at the state and regional level may include university scientists, state and regional 
policy makers, regional offices of governmental agencies, regional agricultural lenders and land managers, commodity boards, advisers, and growers. The role of weed scientists is to understand the complexity of the agricultural community, to listen to the members of this community, and to work as part of the community of stakeholders to find diverse technical solutions that will work at the local level. Many weed scientists have always worked to find and provide information about technical solutions; however, weed scientists now need to take the next step and participate intimately as members of the community, rather than simply delivering the knowledge of these new technologies (Sayer et al. 2013). Jordan et al. (2002) provide a thoughtful discussion and review of how public scholarship, defined as work within the diverse community, may help weed scientists be more effective and efficient in addressing the challenges of increasing diversity and sustainability of weedmanagement practices. The authors discuss how public scholarship moves engagement beyond weed scientists' traditional role of serving in a consultant or advisory capacity to full participation as a member of the community. Community engagement leads to research that addresses the questions and issues raised by growers. To succeed in this type of arrangement, weed scientists need to develop or strengthen interdisciplinary partnerships, particularly with economists and rural sociologists, to initiate new approaches to understanding and to effectively communicate with all the stakeholders who impact production decisions (Doohan et al. 2010; Ervin and Jussaume 2014; Jordan et al. 2002). Examples showing different forms of engagement between weed scientists and growers include the Zero Tolerance Program to manage Palmer amaranth (Amaranthus palmeri S. Wats.) and the Harrington Seed Destructor that has been integrated into rigid ryegrass (Lolium rigidum Gaudin) management practices (Barber et al. 2015; Walsh et al. 2012). The key to successful community-based programs is based on the principles of learning how to work together by identifying short- and long-term targets that all stakeholders agree on, as well as a willingness to adapt programs based on experience (landscape principles 1 and 2 from Sayer et al. [2013]). The common goal for both these example programs is to reduce the soil seed bank of Palmer amaranth in the Zero Tolerance Program and rigid ryegrass for the Harrington Seed Destructor. The programs and approach differed for these two cases; however, both programs were grower-driven and changed over time based on grower experiences. In addition, both programs required a fundamental understanding of the biology of the target weeds.

Within this environment of community-based partnerships, current and accurate information is the foundation for meaningful engagement on the part of the weed scientist. We are not suggesting that good research is not important to the effort. Weed scientists must continue their research to understand the biology and ecology of weeds and weed complexes, how location influences that ecology, and how management choices influence the evolution of the weed spectrum. However, local experience will provide proactive, grower-driven solutions, valuable ground truth of resistancemanagement programs, and complementary research and adoption of practices at the local, state, and regional levels. Weed scientists must collaborate with crop advisers and growers to make sure that practices can be operationally and economically implemented by farmers. Research must also address sustainability and consider all the social and economic factors, as well as collateral effects, that producers face when making and implementing decisions (Ervin and Frisvold 2014; Hurley and Frisvold 2014; Jussaume and Ervin 2014; Owen 2014). The key to understanding these nonweedscience factors is collaborating with economists and social scientists to work within the production community.

\section{National Actions}

Resistance has become a national issue as herbicide-resistant weeds evolve in many production systems across the country (Shaw 2014). Nationally, a general, overarching message about the causes of, and solutions to, managing herbicideresistant weeds is imperative and must be based on the best science available. The national message must also stress the need for well-trained scientists and practitioners in the field of weed science to address this issue. In addition, weed scientists from across the United States must work with national commodity organizations, industry, government, and nongovernmental organizations to deliver the message that production practices, crops grown, farm size and operations, and weed spectrum change from one region to the next. This adds a layer of complexity because although the overarching message must be consistent and based on science, solutions to resistance management must also be tailored to local circumstances. 
At the national level, organizations such as American Society of Agronomy and the National Association of Independent Crop Consultants, which certify agronomists, should include a herbicide-resistance specialization and a level of knowledge of resistance-management practices in their base integrated pest management performance objectives. It will be crucial to certify those professionals who have been educated on the key elements of resistance plans, so that growers, manufacturers, and government agencies know they are working with expert advisers in the field of resistance management. The foundation for building collaborations to address the issue of herbicideresistant weeds is the continuing need for factual, correct information from which to design effective weed-management strategies. A centralized Web portal that identifies peer-reviewed, science-based materials on herbicide resistance and management could be developed and hosted by the Weed Science Society of America for educators and producers to find proven practices to manage weeds. In addition, communication among weed scientists and their collaborators is needed to facilitate sharing of successes and failures, sharing communication tools and messages that have resonated with new audiences, sharing strategies for developing community-based weed management of herbicideresistant weeds, sharing emerging issues, and providing a venue to explore new collaborations among scientists.

In conclusion, the current outreach methods for effecting change in herbicide-resistance management are insufficient. Weed scientists must develop interdisciplinary partnerships and use diverse, nontraditional approaches to address the problem of herbicide resistance. It will take a community of stakeholders working together to make effective weed-management choices that fit with local production practices. The role of the weed scientist can no longer be to provide credible educational materials to help growers, advisers, and the production community make these decisions, they must, instead, serve as collaborators within an active community to ground-truth that material. The production system must be continually evaluated and adapted, based on sound weed-science research and an approach to problem solving that includes the human dimension of the problem to meet the challenges of managing herbicide-resistant weeds. Unfortunately, we cannot recommend a single action or change that needs to be made to extension service programming to be more effective. Specific strategies must be developed in collaboration with the community and after a thorough evaluation of the structure of local communities and the development of relationships with those community members. We are recommending that we all need to reevaluate how we approach our work as educators based on the production system and community of influencers with whom we work. This means that weed scientists need to reach out, develop new partnerships to inform their work, listen effectively, and become an engaged member of the community.

\section{Acknowledgments}

Dr. Schroeder contributed to this article in her personal capacity. The views expressed are her own and do not necessarily represent the views of the United States Department of Agriculture or the United States government.

\section{Literature Cited}

Arbuckle JG Jr, Sternweis L (2014) Farmer Perspectives on Pesticide Resistance: New Report from Iowa Farm and Rural Life Poll. Ames, IA: Iowa State University Extension and Outreach PM 3070. 9 p

Barber LT, Smith KL, Scott RC, Norsworthy JK, Vangilder AM (2015) Zero Tolerance: A Community-Based Program for Glyphosate-Resistant Palmer Amaranth Management. Little Rock, AR: University of Arkansas, Division of Agriculture and Natural Research and Extension FSA2177. http://www.uaex. edu/publications/pdf/FSA2177.pdf. Accessed February 3, 2015

Cloyd RA (2005) Extension education methods: challenges to extension programming. Horttechnology 15:177-180

Doohan D, Wilson R, Canales E, Parker J (2010) Investigating the human dimension of weed management: new tools of the trade. Weed Sci 58:503-510

Ervin D, Frisvold G (2014) Herbicide Resistance Summit II: Community-Based Approaches. http://wssa.net/wp-content/ uploads/Composite $\% 20$ Summit $\% 20 I I \% 20$ Presentations $\% 20$ Final.pdf. Accessed February 3, 2015

Farnsworth RL, Moffitt LJ (1984) Farmers' perceptions and information sources: quantitative analysis. Agric Econ Res 36: $8-11$

Frisvold GB, Hurley TM, Mitchell PD (2009) Adoption of best management practices to control weed resistance by corn, cotton, and soybean growers. Agbioforum 12:370-381

Givens W, Shaw DR, Neuman ME, Weller SC, Young BG, Wilson RG, Owen MD, Jordan DL (2011) Benchmark study on glyphosate-resistant cropping systems in the United States, part 3: grower awareness, information sources, experiences and management practices regarding glyphosate-resistant weeds. Pest Manag Sci 67:758-770

Heap I (2014) International Survey of Herbicide Resistant Weeds. http://weedscience.com/summary/home.aspx. Accessed February 3, 2015

Hurley T, Frisvold G (2014) Herbicide Resistance Summit II: Economics of Resistance Management. http://wssa.net/wp- 
content/uploads/Composite\%20Summit \%20II\%20 Presentations\%20Final.pdf. Accessed February 3, 2015

Jordan N, Gunsolus J, Becker R, White S 2002 Public scholarship-linking weed science with public work. Weed Sci 50:547-554

Jussaume RA, Ervin D (2014) Herbicide Resistance Summit II: Understanding the (Holistic) Decision Making Process in Weed Management to Better Effect Change. http://wssa.net/ wp-content/uploads/Composite $\% 20$ Summit $\% 20 I I \% 20$ Presentations\%20Final.pdf. Accessed February 3, 2015

Johnson WG, Owen MDK, Kruger GR, Young BG, Shaw DR, Wilson RG, Wilcut JW, Jordon DL, Weller SC (2009) U.S. farmer awareness of glyphosate-resistant weeds and resistance management strategies. Weed Technol 23:308-312

Llewellyn RS, Pannell DJ (2009) Managing the herbicide resource: an evaluation of extension on management of herbicide-resistant weeds. Agbioforum 12: 358-369

Norsworthy JK, Ward SM, Shaw DR, Llewellyn RS, Nichols RL, Webster TM, Bradley KW, Frisvold G, Powles SB, Burgos NR, Witt WW, Barrett M (2012) Reducing the risks of herbicide resistance: best management practices and recommendations. Weed Sci 60 (Special Issue):31-62

Oreszczyn S, Lane A, Carr S (2010) The role of networks of practice and webs of influencers on farmers' engagement with and learning about agricultural innovations. Journal of Rural Studies 26:404-417

Owen MDK (2014) Herbicide Resistance Summit II: Approaches to holistic weed management in order to manage herbicide-resistant weeds. http://wssa.net/wp-content/uploads/ Composite\%20Summit\%20II\%20Presentations\%20Final. pdf. Accessed February 3, 2015

Owen MDK, Beckie HJ, Leeson JY, Norsworthy JK, Steckel LE (2014) Integrated pest management and weed management in the United States and Canada. Pest Manag Sci 71:357-376. DOI: $10.1002 / \mathrm{ps} .3928$

Riar DS, Norsworthy JK, Steckel LE, Stephenson DO, Eubank TW, Scott RC (2013a) Assessment of weed management practices and problem weeds in the midsouth United States- soybean: a consultant's perspective. Weed Technol 27:612622

Riar DS, Norsworthy JK, Steckel LE, Stephenson DO, Eubank TW, Scott RC (2013b) Adoption of best management practices for herbicide-resistant weeds in midsouthern United States cotton, rice, and soybean. Weed Technol 27:788-797

Ross MA, Lembi CA. (2009) Applied Weed Science: Including the Ecology and Management of Invasive Plants. 3rd edn. Upper Saddle River, NJ: Pearson Prentice Hall. Pp 99-128

Sayer J, Sunderland T, Ghazoul J, Pfund J, Sheil D, Meijaard E, Venter M, Boedhihartono AK, Day M, Garcia C, van Oosten C (2013) Ten principles for a landscape approach to reconciling agriculture, conservation, and other competing land uses. Proc Natl Acad Sci USA 110:8349-8356

Scott BA, VanGessel MJ, White-Hanson S (2009) Herbicide resistant weeds in the United States and their impact on extension. Weed Technol 23:599-603

Soteres J, Everman W, Glasgow L, Ingegneri L, Schroeder J, Shaw D, Stackler, Tardif F (2011) Herbicide Resistance Education and Training Modules, Weed Science Society of America. http://wssa.net/LessonModules/herbicide-resistantweeds/index.htm. Accessed February 3, 2015

Shaw D, (2014) Herbicide Resistance Summit II: Introduction. http://wssa.net/wp-content/uploads/Composite $\% 20$ Summit\%20II\%20Presentations\%20Final.pdf. Accessed February 3,2015

Walsh MJ, Harrington RB, Powles SB (2012) Harrington seed destructor: a new nonchemical weed control tool for global grain crops. Crop Sci 52:1343-1347

Wilson RS, Hooker N, Tucker M, LeJeune J, Doohan D (2009) Targeting the farmer decision making process: a pathway to increased adoption of integrated weed management. Crop Prot 28:756-764

Received April 22, 2015, and approved July 29, 2015.

Associate editor for this paper: Sarah Ward, Colorado State University. 